\title{
CURRENT STATUS OF STATE FINANCIAL CONTROL OF UKRAINE AND WAYS OF ITS IMPROVEMENT
}

\author{
Sergiy Bardash' ${ }^{1}$, Tatiana Osadcha²
}

\begin{abstract}
The urgency of the research is conditioned by the crisis of state financial control in Ukraine, in particular by the artificial lowering of the role of the state financial control for public administration in terms of determining the problems and prospects of the socio-economic development of the country. The study is evaluating the results of control measures conducted by the State Audit Service of Ukraine and the Accounting Chamber of Ukraine, development of recommendations for their improvement and phrasing. The methodological framework of the research is a comparative analysis of the series of dynamics of the established financial violations, systematic analysis of the quantitative and qualitative composition of the revealed violations, cause-and-effect analysis of the dynamics of the revealed financial violations, abstract-logical method, synthesis and generalization to substantiate the basic theoretical provisions, formulation of conclusions. The scientific results. Based on the performance evaluation of state financial control the article proves the failure of contemporary inquiries to support the interests of the state and civil society, defines the main reasons of such inconsistency. It is also determined that the significant improvement of the situation can be achieved through: awareness of the importance of the parliament and government of state control as an exclusive functionality tool of information source for nationwide scale management decisions centers about the actual situation in the national economy; accomplishment of the concept of preventive controls to facilitate optimization controls, saving budget funds for their implementation and state control servicing, establishment of the necessary evidence for further damages compensation to the state and reduction of the number and volume of financial misconducts in the future; centralization of state financial control, which will consolidate efforts to control completeness of formation, legitimacy, appropriateness and distribution efficiency, redistribution and use of financial resources of the state, eliminate duplication of control tools, create a single database of control tools and their results, optimize servicing costs of state financial control bodies. The practical significance of the research is to develop first-priority recommendations for improving the organizational foundations of state financial control and methods of conducting control measures. Significance/originality. The results obtained form an integrated view of the consequences of functioning of the state financial control bodies, the level of legal consciousness, professional competence and responsibility of officials of state authorities, local self-government, and other entities of economic relations for the consequences of managing state financial resources.
\end{abstract}

Key words: state financial control, financial resources, financial misconduct, preventive control system, centralization.

JEL Classification: M41, M42, M48

\section{Introduction}

Permanent changes in approaches to the management of the Ukrainian economy without a well-defined strategy of state development have made inevitable a radical transformation of one of the most important elements of state administration: state control. The result of such changes has been that the state financial control (hereinafter referred to as SFC) lost its effectiveness, it became inherently episodic, haphazard, situational, fragmentary coverage of financial, including budgetary and tax, relations of the entities of the national economy. According to many experts, about $50 \%$ of Ukraine's economy is in the shadow, financial distortions tend to increase. Creation of specialized anti-corruption bodies in no way affected reduction of corruption in Ukraine. The current state of parliamentarism, the selectivity

\footnotetext{
Corresponding author:

${ }^{1}$ National University of Life and Environmental Sciences of Ukraine, Ukraine.

E-mail: serg.bardash@gmail.com

ORCID: http://orcid.org/ 0000-0001-5711-5229

ResearcherID: F-4116-2018

${ }^{2}$ Kherson State University, Ukraine.

Email: tatiana@osadcha.com

ORCID: http://orcid.org/0000-0003-4258-0907

ResearcherID: F-4110-2018
} 
and fragmentation of parliamentary control, as well as the incompleteness of the transformation process of SFC do not allow to control the legality, expediency and efficiency of distribution and use of state financial resources by state authorities, local self-government bodies, entities of state ownership, to operate reliable information on the socio-economic status of the national economy to develop a long-term and mediumterm strategies for its development.

Insufficient scientific elaboration of issues of organization, coordination of actions of SFC bodies, methods of its conducting is one of the reasons for strategic errors in the system of management of the economy of Ukraine.

Throughout Ukraine's independence, the effective management of state property and funds remains the question of the day. The SFC system should play a major role in this matter, however, as the experience of its entities shows, the country's government is satisfied with the composition and efficiency of the SFC system. According to Hetherington (1998), the inconsistency of state authority actions with the expectations of the Ukrainian citizens led to low living standards, impeded development and excessive corruption.

One of the few elements of the SFC system is the state audit institution, which is able to guarantee and promote confidence to state authority at the macro level by determining the economic feasibility, efficiency and effectiveness of the country's resource management and quality of the state control (Heald, 2018).

This conclusion is confirmed by the positive experience of the EU countries, as well as the USA, Canada and other countries in this field. Hay and Cordery (2018) emphasize that public sector auditing as it is currently known is old-established, dating from the 1860 s, but also a living organism that continues to change. The authors draw parallels between independent audit and public audit and substantiate that there are many explanations that can be applied to examine the value of public audit, including agency, signaling, insurance, management control, governance and confirmation of explanations (Hay, cordery 2018).

Based on the deep analysis of scientific publications and history, Hay and Cordery (2018) conclude that further productive research should include comparative studies of Supreme Audit Institutions and their impact; examination of changing governance practices in the public sector and their impact on auditing. Regarding this, the researches based on a cross-national comparison are useful (Bowerman, et al., 2003; Blume; Voigt, 2011; Morin, 2016; Jeppeson, et al., 2017).

Interethnic comparison plays a significant role in identifying deficiencies in the functioning of the SFC system of Ukraine, but domestic researchers continue to seek ways to improve it.

Recently, the issues of development of state financial control under the conditions of market economy of
Ukraine (Basancov, 2008); development of financial control system in Ukraine (Vyghovsjka, 2010); current models of the SFC system in the countries of the European Union, organizational and functional structure of the SFC system, status and problems of its development (Ivanova, 2010); organization and implementation of state control in Ukraine (Dmytrenko, 2011); organization of the system of state financial audit in Ukraine (Slobodjanyk, 2014); the essence of the SFC system (Shevchuk, 2015) continue to be raised in specialized scientific circles. I. Drozd, V. Symonenko, I. Stefaniuk and others also continue to investigate the theoretical, methodological and practical aspects of SFC actively. However, positively assessing the individual results of domestic scientists in the search for ways to build an effective SFC system in Ukraine, it should be noted the fact that there are significant deficiencies in its functioning, which provides certain grounds for the recognition of SFC as one of the significant factors inhibiting the development of Ukraine's economy.

The objectives of the research are to evaluate the performance of the SFC bodies, to provide recommendations for their improvement, and to formulate proposals for the transformation of the SFC system.

\section{Characteristics of the state financial control indicators}

Economic changes in the development of the public sector of economy accompanied by the requirement of fierce competition in the world market, the necessity of rational use of financial resources should encourage public authorities to reconsider their attitude towards SFC. This is due to the fact that over the last decade the state has in fact lost a coordinating and guiding role in the formulation of policies regarding the management of state property and state financial resources. An indirect proof of this fact is the strong desire of the government of Ukraine to announce annually the sale of sufficiently attractive state-owned enterprises, since the theses about the inefficiency of management of state-owned enterprises are heard all the time including from the leadership of the government.

Existing problems of public administration caused the institutional imbalance of SFC. The state of fiscal discipline has deteriorated significantly, which threatens Ukraine's national security in the financial sphere.

Extensive facts of theft of budget funds, other violations of financial and property character continue to be revealed from year to year (Figure 1).

This is due to the fact that the number of enterprises, organizations and institutions subject to audit is rapidly decreasing from year to year (80075 in 1997, and 6040 in 2013, 1546 in 2018).

It is significant for further assessment of the level of economic legal consciousness of heads of state-owned 


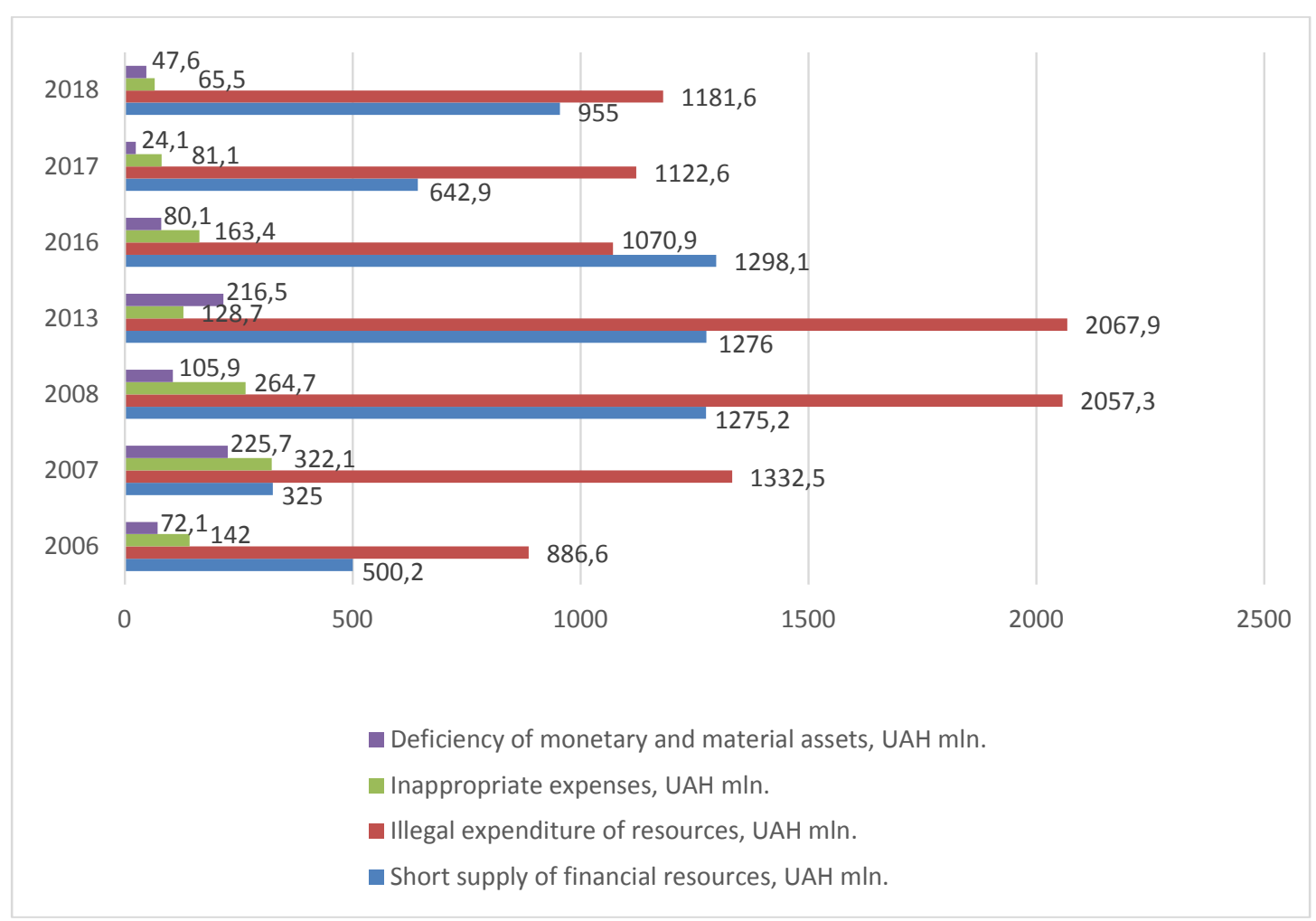

Figure 1. Dynamics of financial violations revealed by the State Audit Service of Ukraine in 2006-2018, UAH mln.

Source: compiled by authors based on materials of Mnykh, 2015, the State Control and Revision Service of Ukraine 2006-2018 (Mnykh, 2015; Derzhavna kontroljno revizijna sluzhba Ukrajiny 2006-2018)

enterprises, organizations and institutions, other budgetary units, as well as the level of preventiveness of the control measures taken and the management decisions made based on their results, that the information that there is a negative tendency to increase the volume of violations, including by their types, except for the period starting from 2016 (Figure 1), as a direct decision of the Prime Minister of Ukraine has been a moratorium established on taking control measures from 2014.

It is worth noting also that the figures of the volume of violations detected by the State Audit Service of Ukraine (hereinafter referred to as SAS) and the Accounting Chamber of Ukraine (hereinafter referred to as ACU) in 2006-2015 (Figure 2) allow us to make certain assumptions about certain trends of the attitude of the state authorities to SFC.

In particular, an increase in the volume of revealed violations by 2010 (Figure 2) may indicate either an increase and uncompromising functioning of the SFC system, or a very unprofessional management of public resources (in 2010, the AC revealed violations amounted to UAH 52 billion, the SAS revealed violations amounted to UAH 12.1 billion). The trend of change in indicators of revealed violations after 2010 may indicate the existence of political pressure on the activities of the SFC entities, which, in our opinion, could condition the selectivity of control measures and response to their results, which resulted in a significant decrease in the volume of violations revealed. Thus, in 2018, the AC revealed violations amounted to UAH 17 billion, and the SAS - UAH 2.250 billion. These indicators are a definite proof of the above thesis against the comparison of expenditures of the State Budget of Ukraine in 2010 - about UAH 308 billion and in 2018 about UAH 918 billion. For specialists it is clear that a significant decrease in the indicators of the revealed violations is not a consequence of increasing the level of responsibility for taxpayers' funds management and conscious adjustment of economic interests of top management of state-owned enterprises, institutions, organizations, as well as other budgetary units for the benefit of the Ukrainian citizens.

The above considerations are made against the background of the awareness of the fact that the economicinterests of individuals, endowed with the state power, and the overwhelming majority of the Ukrainian citizens who have chosen a pro-European choice for the development of the country, are inconsistent. In particular, the volumes of financial violations established by the AC in 2016-2018 indicate the postponement of positive changes in the management of public resources (Figure 3).

When characterizing the quality of public resources management, it should be borne in mind that the most widespread violations offinancial and budgetary discipline 


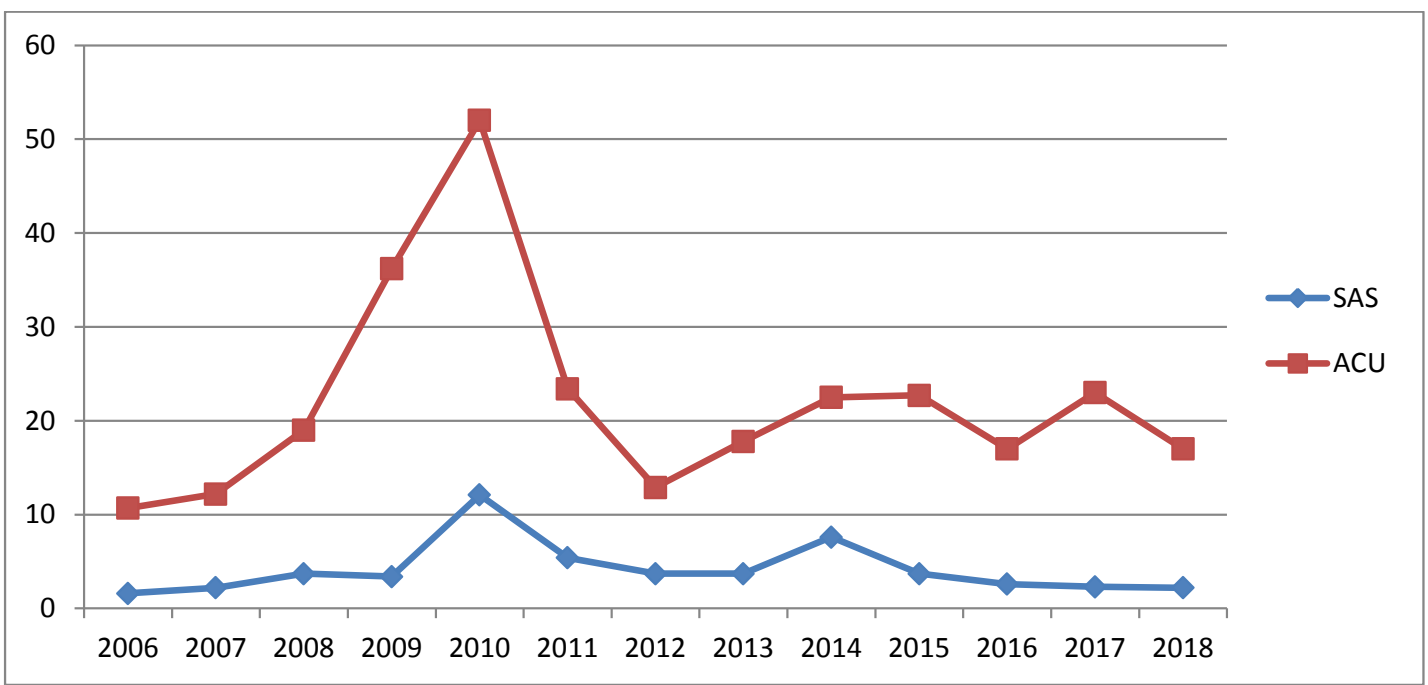

Figure 2. Volumes of violations revealed by the State Audit Service of Ukraine and the Accounting Chamber of Ukraine in 2006-2018, UAH Billion

Source: compiled by authors based on materials of the State Control and Revision Service of Ukraine, 2006-2018, the Accounting Chamber of Ukraine, 2015-2018 (Derzhavna kontroljno revizijna sluzhba Ukrajiny, 2006-20018, Rakhunkova palata Ukrajiny, 2015-2018)

in the country remain from year to year: violation of the requirements of the budget code in terms of misuse of budgetary funds, taking for payment commitments in excess of the approved supplies, diversion of budgetary funds to long-term receivables; unnecessary spending of budgetary funds as a result of payment of excessive amounts and cost of works performed and services rendered; spending of budgetary funds for the purchase of furniture, equipment, vehicles and other material assets in excess of the limit standards, as well as costs for the maintenance of vehicles beyond the set limits; unlawful transfer of state and communal property to entities of non-governmental ownership; failure to apply mandatory public procurement procedures; depreciation of assets as a result of non-indexation, as well as a result of non-acquisition of acquired property and surplus of commodities and materials.

Presently, in order to realize the need to strengthen control over public funds management processes, the relative indicators shown in Figure 4 gain in importance (Rakhunkova palata Ukrajiny, 2018).

The realization that there is no improvement in budgetary discipline today, no strengthening of a responsible attitude to the management of public resources is observed, in our opinion, conditioned the fact that the Accounting Chamber of Ukraine refused to provide structured data on the causes of violations revealed in 2018 (Rakhunkova palata Ukrainy, 2018).

Based on the dynamics of the number of control measures carried out by the SFC bodies, it can be argued that functioning of both the public administration system and the SFC system is at an unsatisfactory level, as evidenced also by a number of macroeconomic indicators of the state of the national economy, in particular, contraction in manufacturing, public budget deficit, and public debt growth etc.

One of the factors of the unsatisfactory assessment of the activities of the SFC bodies by civil society is the low level of compensation for the damages caused, which in turn leads to the non-implementation of the preventive function by the financial control. Thus, the number of enterprises, institutions and organizations audited by the SAS decreased from 80075 units in 1997 to 1546 units in 2018, but this did not reduce the number and monetary estimate of violations. Thus, in 1997, on average, one audited enterprise (institution, organization) had violations in the amount of UAH 18038, and in 2009 this indicator was equal to UAH 210526, which is 11.7 times higher than in 1997. Average compensation for 1997-2009 amounted to $42.7 \%$. In absolute terms, the compensation amounted to UAH 8787.6 million, or $42.45 \%$, for 11 years. Accordingly, UAH 11911.8 million remained uncompensated (Bardash, 2008).

The stated negative trend is observed today too. Thus, according to the SAS statistical reports for 20162018 (Derzhavna kontroljno revizijna sluzhba Ukrajiny, 2016-2018), the average percentage of compensation and expenditure renewal carried out in violation of the law made $24.2 \%$. In general, when assessing the quality of the materials of the control measures conducted by the SAS, it should be noted that for 2016-2018, the average percentage of eliminated financial violations that led to the loss of financial material resources, taking into account violations revealed in previous years, was $33.5 \%$. It should also be noted that in 2018, the SAS inspected 1546 enterprises, institutions and organizations, which was $1.93 \%$ of the indicator of 1997. 


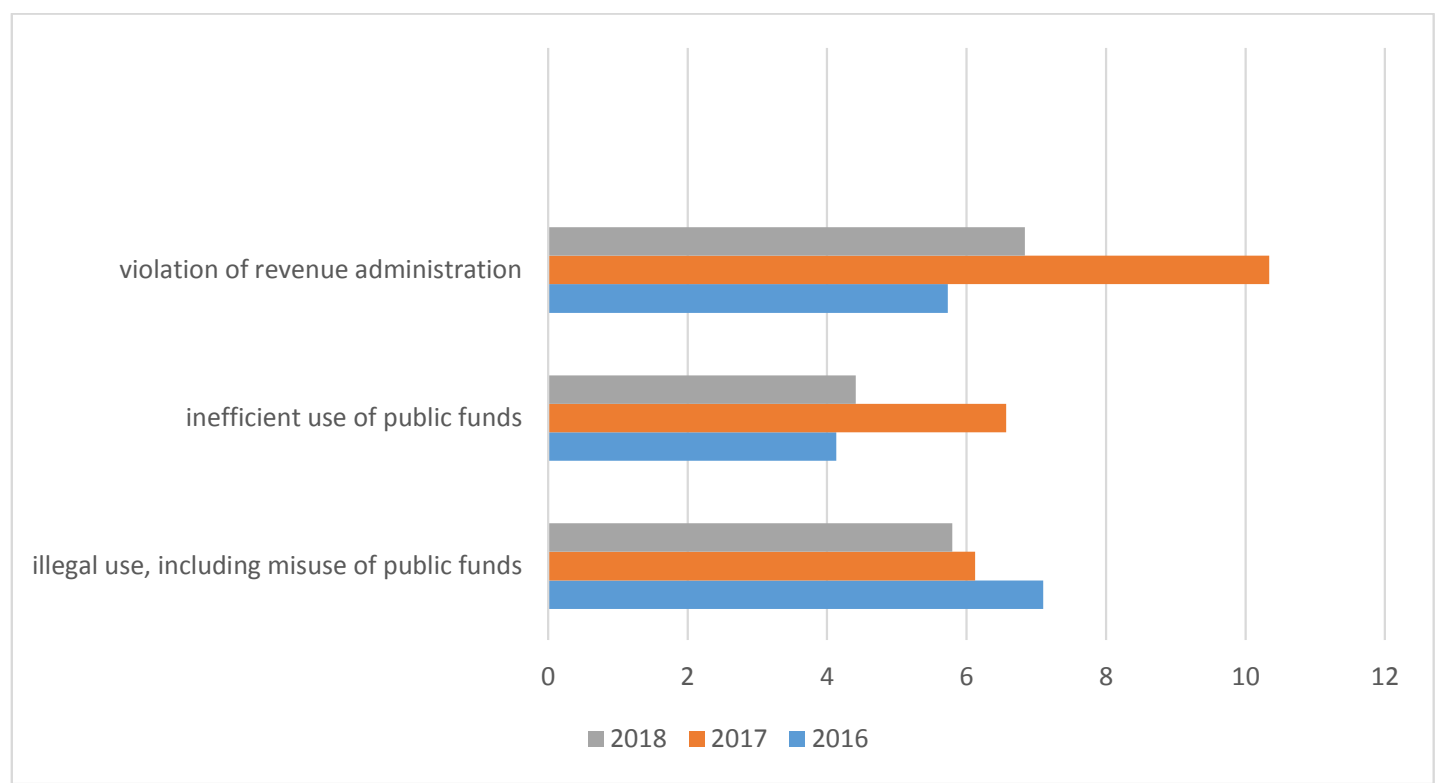

Figure 3. Types of violations revealed by the Accounting Chamber of Ukraine in 2016-2018, UAH Billion

Source: compiled by authors based on the Accounting Chamber of Ukraine, 2015-2018 (Rakhunkova palata Ukrajiny, 2015-2018)

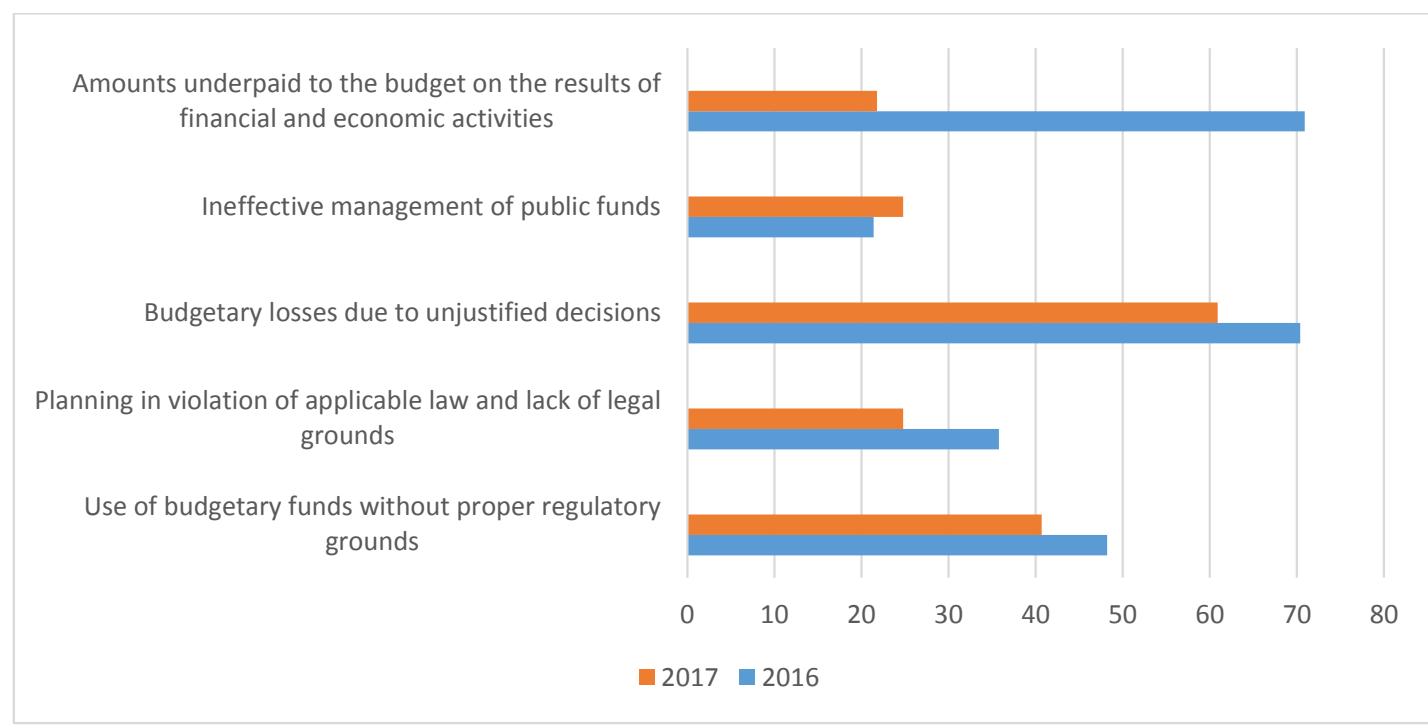

Figure 4. Some relative indicators of the causes of violations revealed by the Accounting Chamber of Ukraine in 2016-2017,\%

Source: compiled by authors based on the Accounting Chamber of Ukraine, 2016-2017 (Rakhunkova palata Ukrajiny, 2016-2017)

The stated situation regarding the level of compensation for the damage caused to the state gives grounds to suggest that the system of law enforcement agencies, as well as the courts, do not contribute to the protection of the interests of the state, since the quality of the material on the revealed financial violations is so low that in fact there is no possibility to make motivated court decisions to compensate the State for the damage caused.

It is worth paying attention to the fact that inappropriate response of heads of the state authorities to managerial decisions of heads of departmental enterprises and institutions in whose economic activities financial irregularities have been revealed does not contribute to eliminating and preventing violations in the future.

\section{Directions of improvement of the system of state financial control in Ukraine}

Therefore, the preventive function of the SFC control measures remains declared, since the financial violations do not diminish. Their numbers and varieties are only 
increasing. Elimination of the identified deficiency can be achieved by implementing the concept of preventive control based on implementation of hypotheses about possible violations and versions of their commission in the control process. This concept is aimed at achieving a new quality of functioning of the financial control system at all levels, as well as optimizing the process of monitoring the indicators of its duration and resource saving for its implementation, formation of evidence base for further compensation for the damages caused, as well as determining measures to eliminate the revealed violations and preventing them from occurring in the future.

The above methodological proposal is aimed at improving the performance of the SFC bodies, but the deficiencies identified in the research should be eliminated by applying a conceptual systematic approach to addressing them, taking into account measures to improve the public administration system. That is why it is time to create a coherent SFC system, based on uniform organizational and methodological principles. Such a system should adequately respond to the numerous economic problems that arise in the implementation of financial relations in the formation, distribution and use of financial resources, to ensure the unity and stability of organizational and economic links between branches of the legislative and executive power, to cover all sectors and levels of the economy.

It should be noted that in addition to the abovementioned features of the new desired quality of the SFC system of Ukraine, there should be a significant improvement in the organizational structure, content of control measures, financial, personnel, information support, establishment of close relations with other state control bodies, etc. However, there is also a time to coordinate the activities of the SFC bodies, since control measures, which are sometimes duplicated, are carried out at the expense of a single source, which is the budgetary funds, including taxpayers' funds.

Lack of a clear understanding of the format of relationships and the purposeful focus of functioning of the state control bodies at the levels of the legislative and executive branches of power, as a rule, is the main reason for strategic failures in the public administration system.

Currently, scientists are proposing several approaches tothetransformation ofthecurrentsystemofstatecontrol, starting with the development and implementation of the concept of the SFC development, to proposals for improving the current regulatory prescription of the activity of state control bodies, the introduction of new forms of control, etc. The suggestions presented in the domestic scientific literature are aimed at resolving the issue of the establishment of the main SFC body or the separation of powers between the legislative and executive branches of power. Accordingly, the issues of coordinated resolution of state control problems remain unresolved.
Today, only a set of disparate chains of state control operates in Ukraine, which do not interact sufficiently with each other, it is not a system in the scientific sense. In fact, the modern national SFC is a collection of state control bodies of the legislative and executive branches of power, which perform disparate, uncoordinated control functions, so, taking into consideration the theory of system classification, such a set is difficult to recognize a complete system and identify:

- "as a complex system, because there are no interconnections and interactions between a large number of public authorities that can be recognized as simple systems. If they exist, they are only one-sided in nature between the executive branch control bodies;

- as a large system, because: the intended purpose of subsystems (separately for the legislature and separately for the executive branch) or simple systems (for separate bodies of state control) are not always subordinated to the purpose of the whole system; there is a lack of large amount of information links between the subsystems; there are no elements of self-organization (in the vast majority of state control bodies of the executive branch of power);

- as a purposeful system, because the totality of state control bodies does not have the ability to form and change in whole as a system in the processes of adaptation to the environment and development" (Bardash, 2009).

Other significant disadvantages of SFC are the lack of a unified informational and methodological base, as well as its imperfect legal regulation, which significantly reduces its effectiveness and complicates the achievement of the defined purpose.

One of the possible ways of solving the established deficiencies should be considered centralization of the activity of the SFC bodies, which will contribute to the construction of a unified system of state control based on unified organizational and methodological principles, unified rules of functioning and solution of the set tasks with a clear definition of the control bodies and distribution of their functions and powers.

This proposal in no way contradicts national trends in decentralization, since the latter has been chosen as a possible option to eliminate the effects of financial centralization. State control over Ukraine's independence period has never been centralized, on the contrary, there has been an unjustified increase in state control bodies, which, in our opinion, has sometimes led to justified claims for their activity.

Nowadays, the organizational structure of the highest bodies of state control of the leading countries of the world is decided differently, based on their historical development and selected strategies of their socioeconomic development. It is worth noting that at present we cannot fully transfer the experience of the state control organization in the developed countries of the world into domestic practice for the following reasons: insufficient development of the national 
system of public administration; absence of a strategy for the development of the national economy and the identification of the main tasks of state control bodies in the context of its development. However, a transformation of the state control system is needed, so it is worth considering a model that would create the organizational preconditions for its effective functioning and would form the basis of its conceptual restructuring.

Such transformation should be based on:

- establishment of a control body, to which all other state control bodies, both of the legislative and executive branches, would be subordinated;

- the integrity of the state control system as an element of the public administration system;

- introduction of random checks of the data obtained by the state control bodies based on the results of the control measures carried out.

The first step aimed at recognizing the state control bodies by the system should be the construction of two subsystems: the bodies of control of the legislative and separately executive branches of power (the AC and territorial accounting chambers, as well as the SAS respectively, headed by other bodies of state control in the system of executive power).

The next step is to centralize a complex system to coordinate subsystem activities, eliminate duplication of control measures, and optimize expenditures for their conducting.

We believe that the most appropriate proposal is to create a unified collegial body (for example, the State Control Bureau), which would include representatives of the existing SFC bodies.

According to functional tasks, this Bureau should be the body of strategic management, overall planning and ongoing coordination of SFC in Ukraine. The main activities of this body should be:

- approval of a unified annual plan of control measures, which should be based on the annual plans of the AC and SAS, as well as prospective plans of control activities. Within the framework of the stated proposal, the SASU as the main body of state control of the executive power, should develop a general plan taking into account the plans of control measures of the State Fiscal Service of Ukraine, as well as the plans of control measures of other state control bodies of the executive power;

- improvement and development of standards for control measures, as well as methods of assessing their effectiveness;

- carrying out of random quality control of the implemented control measures.

The State Control Bureau should be at the forefront in establishing an integrated system of external and internal state control, implementing international standards of state control, aligning them and harmonizing with national legislation as one of the significant factors that will significantly affect the quality of control measures and significantly reduce the level of corruption.

\section{Conclusions and further researches}

The conducted research according to its purpose gave the grounds to reach the following conclusions:

1. The activity of the state financial control bodies of Ukraine does not meet the current requirements for guaranteeing the interests of the state and civil society and is correlated with the overall assessment of the activity of all public authorities. The main reasons for this assessment are as follows:

- reduction of the level of interest of the governing bodies of state power in carrying out control over the distribution and expenditure of financial resources, in addition to controlling the completeness and timeliness of formation of the revenue part of the state and local budgets;

- low level of compensation for the damages caused to the state;

- insufficient preclusiveness of control measures, which causes the volume and types of financial violations to increase.

2. State control must meet a number of requirements that are determined by the interests of the state. First of all, it is about ensuring the effectiveness of the activities of the bodies that make up its power apparatus, and of the total system as a whole. An important condition for ensuring the effect of the functioning of state control bodies is the systematicity, optimality and balance of their control actions. Failure to comply with at least one of these conditions leads to the inefficient functioning of the entire system of state control, as well as, in the future, the public administration system.

3. Substantial improvement of the activities of the SFC bodies can be achieved through:

- awareness of the importance of state control by the parliament and the government, as the only instrument for providing the centers of decision-making of national importance with information on the actual state of affairs in the national economy;

- implementation of the concept of preventive control, which will help to optimize control measures, to save budgetary funds for their implementation and maintenance of the state control bodies, to create the necessary evidence base in order to further compensation for the damages caused to the state, as well as to reduce the number and volume of financial violations in the future;

- centralization of SFC, which will consolidate efforts to control the completeness of the formation, legality, expediency and effectiveness of the distribution, redistribution and use of public financial resources, eliminate the facts of duplication of control measures, create a unified information base on control measures and their results, optimize the cost of maintaining the SFC bodies.

The implementation of these proposals will improve SFC and ensure a sufficient level of financial security of the country. 


\section{References:}

Bowerman, M., Humphrey, C., \& Owen, D. (2003). Struggling for supremacy: the case of UK public audit institutions. Critical Perspectives on Accounting, vol. 14, no 1-2, pp. 1-22.

Blume, L., \& Voigt, S. (2011). Does organizational design of supreme audit institutions matter? A cross-country assessment. European Journal of Political Economy, vol. 27, no 2, pp. 215-229.

Basancov, I. V. (2008). Rozvytok derzhavnogho finansovogho kontrolju v umovakh rynkovoji ekonomiky Ukrajiny [Development of state financial control in the conditions of market economy of Ukraine]. The dissertation author's abstract for the degree of Doctor of Economic Sciences.

Bardash, S. V. (2010). Ekonomichnyj kontrol'v Ukraini: systemnyj pidkhid [Economic control in Ukraine: system approach]. Kyiv: Kyiv National University of Trade and Economics.

Bardash, S. V. (2008). Kontrol' diial'nosti sub'iektiv hospodariuvannia: hipotezy ta versii porushen' [Control of business entities operations, hypotheses and violations reasoning]. Kyiv: Kyiv National University of Trade and Economics. Bardash, S. V. (2009). On the rationale of centralization of state control in Ukraine. Management, vol. 12, pp. 39-50. Dmytrenko, H. V. (2011). Orghanizacija i zdijsnennja derzhavnogho kontrolju v Ukrajini (finansovo-ekonomichni aspekty) [The organization and implementation of state control in Ukraine (financial and economic aspects]. The dissertation author's abstract for the degree of Doctor of Economic Sciences.

Derzhavna kontroljno revizijna sluzhba Ukrajiny (2006-2015). Zvit pro rezuljtaty dijaljnosti Derzhfininspekciji za 2006-2015. Kyiv: Informatsiino-analitychne ahentstvo. URL: http://www.dkrs.gov.ua/kru/uk/index (accessed December 10, 2019).

Derzhavna kontroljno revizijna sluzhba Ukrajiny (2016). Zvit pro rezuljtaty dijaljnosti Derzhfininspekciji ta jiji terytorialjnykh orghaniv za sichenj-ghrudenj 2016 roku. Kyiv: Informatsiino-analitychne ahentstvo. URL: http://www.dkrs.gov.ua/kru/uk/publish/article/128452 (accessed December 10, 2019).

Derzhavna kontroljno revizijna sluzhba Ukrajiny (2017). Zvit pro rezuljtaty dijaljnosti Derzhaudytsluzhby ta jiji terytorialjnykh orghaniv za sichenj-ghrudenj 2017 roku. Kyiv: Informatsiino-analitychne ahentstvo. URL: http://www.dkrs.gov.ua/kru/uk/publish/article/132220 (accessed December 10, 2019).

Derzhavna kontroljno revizijna sluzhba Ukrajiny (2018). Zvit pro rezuljtaty dijaljnosti Derzhaudytsluzhby ta jiji terytorialjnykh orghaniv za sichenj-ghrudenj 2018 roku. Kyiv: Informatsiino-analitychne ahentstvo. URL: http://www.dkrs.gov.ua/kru/uk/publish/article/139479;jsessionid=58F25AB8EF3AE5C4364D05D5B 74AEE29.app1 (accessed December 10, 2019).

Hay, D., \& Cordery, C. (2018). The value of public sector audit: Literature and history. Journal of Accounting Literature, vol. 40, pp. 1-15.

Hetherington, J. Marc (1998). The Political Relevance of Political Trust. The American Political Science Review, vol. $92(4)$, p. 791-808.

Heald, D. (2018). Transparency-generated trust: The problematic theorization of public audit. Financial Accountability \& Management, vol. 34, p. 317-335.

Ivanova, I. (2010). Derzhavnyj finansovyj audyt: Paradyghmy rozvytku [The State financial audit: evolution paradigms: monograph]. Monograph. Kyiv: Akademvydav.

Jeppeson, K. K., Carrington, T., Catasús, B., Johnsen, A., Reichborn-Kjennerud, K., \& Vakkuri, J. (2017). The strategic options of Supreme Audit Institutions: The case of four Nordic countries. Financial Accountability \& Management, vol. 33, no 2, pp. 146-170.

Morin, D., \& Hazgui, M. (2016). We are much more than watchdogs: The dual identity of auditors at the UK National Audit Office. Journal of Accounting and Organizational Change, vol. 12, no 4, pp. 568-589.

Mnykh, Je. V. (2015). Finansovyj audyt: informacijno-analitychne zabezpechennja [Financial audit: information and analytical support]. Kyiv: Kyiv National University of Trade and Economics.

Rakhunkova palata Ukrajiny (2015). Zvit Rakhunkovoji palaty za 2015 rik. Kyiv: Informatsiino-analitychne ahentstvo. URL: https://rp.gov.ua/upload-files/Activity/Reports/Zvit_RP_2015.pdf(accessed December 1, 2019). Rakhunkova palata Ukrajiny (2016). Zvit Rakhunkovoji palaty za $201 \overline{6}$ rik. Kyiv: Informatsiino-analitychne ahentstvo. URL: https://rp.gov.ua/upload-files/Activity/Reports/Zvit_RP_2016.pdf(accessed December 1, 2019). Rakhunkova palata Ukrajiny (2017). Zvit Rakhunkovoji palaty za $201 \overline{7}$ rik. Kyiv: Informatsiino-analitychne ahentstvo. URL: https://rp.gov.ua/Activity/Reports/?id=9 (accessed December 1, 2019).

Rakhunkova palata Ukrajiny (2018). Zvit Rakhunkovoji palaty za 2018 rik. Kyiv: Informatsiino-analitychne ahentstvo. URL: https://rp.gov.ua/Activity/Reports/?id=133 (accessed December 1, 2019).

Slobodjanyk, Ju. B. (2014). Formuvannja systemy derzhavnogho audytu v Ukrajini [Formation of the state audit system in Ukraine]. Monograph. Sumy: FOP Natalukha A. S.

Shevchuk, O.A. (2015). Sutnistj systemy derzhavnogho finansovogho kontrolju [The essence of the system of state financial control]. Financial space, vol. 1(17), pp. 304-308.

Vyhovs'ka, N. H. (2010). Rozvytok systemy finansovogho kontrolju v Ukrajini [Development of financial control system in Ukraine]. The dissertation author's abstract for the degree of Doctor of Economic Sciences. 